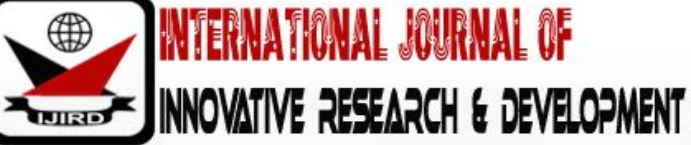

ISSN 2278 - 0211 (Online)

\section{Health Implications of Head Porterage: The Case of the Female Head Porters (Kayayei) in the Central Business District of Accra, Ghana}

\author{
Sulemana Alhassan \\ Research Assistant, Department of Social Work, University of Ghana, Accra, Ghana \\ Dr. Boateng Alice \\ Senior Lecturer, Department of Social Work, University of Ghana, Accra, Ghana
}

\begin{abstract}
:
The kaya business (head porterage) started in Ghana several decades ago. The players in the business are young and adult females called Kayayei, who migrate from the northern parts of Ghana to cities and urban areas in the southern part. The number of Kayayei keeps rising over the years in Accra and other cities. As a result, basic needs, such as decent accommodation and access to basic health care are serious challenges to the Kayayei. This study examined the living and working conditions of the Kayayei in relation with their health. The study adopted a qualitative research design and employed focus group discussions for the data collection. Eighteen kayayei from Tema Station and Agbogbloshie Market constituted the study participants. Three groups of six participants each participated in discussions. The findings of the study showed that the Kayayei lived and worked in appalling conditions, which affected their health.The study also found that the Kayayei were often attacked by malaria and cholera, due to mosquito bites and unwholesome eating habits. Participants were also exposed to vehicular accidents at the lorry stations where they work. The study recommends government and other stakeholders to put resources together to organize health programmes on basic good health practices for the Kayayei, assist the school dropouts among the Kayayei to go back to school and also institute vocational training for the rest, to give them employable skills to enable them take control of their lives, in a more dignified way.
\end{abstract}

Keywords: Kayayei, head porterage, migration, health, health problems

\section{Introduction}

Rural-urban migration has been among the major problems of developing countries. Most people all over the world see migration as a strategic way to escape socio-economic hardships, as well as environmental threats and to seek a preferable life elsewhere (Carballo \& Mboup, 2005).Migration in Ghana, like migration in any part of the world, is partly in response to imbalances in development and unequal distribution of resources between origin and destination areas (Kwankye, Anarfi, Tagoe, \& Castaldo, 2007). For example, educated professionals in Ghana, such as doctors, social workers, teachers among others, migrate to developed countries for greener pastures in the form of better salaries and remuneration. At the same time, uneducated and unskilled persons, such as the Kayayeimigrate from their villages in the northern parts of Ghana to some cities in the southern parts to do menial jobs. Kayayei are female economic migrants, who are mostly within the age range of 8-45, and are usually engaged in various activities, including carrying heavy loads on their heads called Kaya Business, as service to people for a fee (Whitehead \& Hashim, 2005).

A deeper observation of the progressive increase in number of the Kayayei shows that the kaya business has come to stay. An estimated 7,787 Kayayei live and work in the Greater Accra Region (United Nations Population Fund 2011). The kaya business in the past was reported to have improved the living standards of some of the Kayayei. This is because some of the Kayayei were able to raise resources out of the kaya business to start other relatively good businesses and trade both in the cities they operate in and at their hometowns (Yeboah \& Appiah-Yeboah, 2009). It is however the case that the kaya business has now become congested, due to the rise in the number of Kayayei. The estimated number of Kayayei in Ghana is over 50,000 out of which more than 10,000 live in Greater Accra Region(Wilson \& Mittelmark, 2013).

This situation has rendered the business unattractive as compared with the past. The rise in the number of Kayayei has also created over-crowding in their various places of residence, a situation that exposes them to several health challenges (Shamsu-Deen, 2013). Furthermore, $49 \%$ of head porters live in wooden structures in the cities with some working and sleeping in front of kiosks by the road side (Baah-Ennumh et al., 2012) and under market sheds at the major markets in the cities where they operate (Boateng \& Korang-Okrah, 2013), a situation that comes with several health challenges. 


\section{Methods}

This study employed the qualitative design to explore the unhealthy living and working conditions in which the Kayayei survive and the health challenges posed by these conditions. The conditions and experiences the Kayayei go through requireddetail explanation by the Kayayei themselves. The qualitative design was therefore employed to enable the researchers to solicit in-depth lived experiences of the Kayayei in relation to the topic under study.

\subsection{Focus Group Discussions}

Focus group discussions were used for data collection. The focus group discussions provided natural atmosphere for interaction between participants and the researchers and created a smooth outlet for recording attitudes, feelings and behaviours of the research participants (Turner, 2010). The use of focus group discussion as a technique also allowed us to collect data in a natural setting, which created the needed convenience among participants to offer detailed responses to enrich the data (O'neill, 2008). Three focus group discussions were conducted, and each group was composed of six participants.Each focus group discussion session lasted for approximately one and half hours. Upon the permission of the participants, their responses were recorded.

\subsection{Participants}

The study participants comprised of Kayayei from Tema Station and Agbogbloshie Market of the central business district of Accra. Two criteria for inclusion were considered. Firstly, participants were to be Kayayei who worked in and also used Tema Station and Agbogbloshie Market as their residence. Secondly, participants were to have lived and worked as Kayayei at the Tema Station and Agbogbloshie market continuously for at least a year. Staying and working continuously for at least a year exposed participants to the needed in-depth experiences and information this study intended to solicit

\subsection{Data Analysis}

In order to protect the data collected, the recorded data was saved on hard disk of a computer. We then transcribed the raw data from audio to text form. In a bid to ensuring credibility and trustworthiness, we employed member checking, which is a qualitative research data validation technique that is employed by researchers in order to achieve accuracy and credibility of a study (Creswell and Miller, 2000). In line with member checking, we sent back the transcribed data to the participants to help cross check the information to ensure that the data reflected exactly the intent and meanings of the information given by participants during data collection and eventually instill credibility and trustworthiness in this study. We used the Framework Analysis for data analysis: We sifted and sorted the data in accordance with key issues and themes, using four steps namely: familiarization; identifying a thematic framework; indexing; and mapping and interpretation (Srivastava, \& Thomson, 2009)

\section{Results and Discussions}

\subsection{Accommodation}

Accommodation provides shelter for resting and sound sleep as well as security for lives and properties.It is however the case from the findings of this study that the participants in their various working centres did not have decent accommodation to live in. From the findings, a number of theparticipants use the various market sheds and lorry stations as their homes. Those of them living in the open pavements of the stations experience problems during the rainy seasons. Apart from the helpless conditions those of them who sleep in open places encounter, those in rented sheds complained of leaking roofs that resulted in sleepless nights, whenever it rained as summed up by participantsas below:

We use this station as our home. Most of us sleep on the pavement in the station and few of us live in rented sheds. Yes, thieves and rapists do attack us in the night. We have had several rape cases in this station some of which resulted in unplanned and unwanted pregnancies. We believe this can also result in sexual transmitted diseases, but what can we do? It is cheaper to stay here than renting a proper accommodation elsewhere. Even though those living in the sheds do pay for rent, it is not so much. So, we are trying to manage the situation like that, since we cannot afford better places.

We are so crowded in our rooms and our rooms leak whenever it rains. Whenever it rains in the night, we have to keep standing for safety as long as the rain will last. When the rain stops, we clear the water, mop the place and lie on the wet floor. You know, sleeping will be difficult in such a condition. We have sleepless nights whenever it rains and most of us complain of headache after every sleepless night.

The inability of the Kayayei to secure accommodation for themselves is a threat to their health. They use market sheds and pavements of lorry stations as their residence at the mercy of the bad weather, thieves and rapists, a situation that have serious health consequence on them. In line with this (Anarfi, 1993) posited that the situation of these economic migrants is noted to increase their vulnerability to some health problems including reproductive health related complications and other sicknesses resulting from exposure to bad weather. This experience the Kayayei undergo also attests to the findings of Shamsu-Deen (2013) that it is common to find several Kayayei sleeping in market sheds, in and under parked cars and in open places at markets squares and lorry stations in the night, a situation that is so detrimental to their health. From the findings, many of kayayei were found at transport stations and market squares, which double as their places of work and residence. About $80 \%$ of Kayayei working in Tema Station spend the night, some of them with their babies, on the open pavements of the station (Van den Berg, 2007).Living in open places at the commercial areas like the market and lorry station as indicated by participants can expose them to unscrupulous person such as thieves and sometimes rapists. 
Mosteconomic migrants, particularly the Kayayei, work and live on the streets (Opare, 2003) that put them at a high risk of being sexually abused, which can result in contracting sexually transmitted infections, such as HIV and AIDS.

\subsection{Sanitation}

Living in a clean and hygienic environment supports good health. From the findings of this study however, the Kayayeilive in unhygienic and unclean environments, which expose them to several health risks. Most parts of the central business district of Accra where the Kayayei liveare filthy and have choked gutters that brew mosquitoes and pollute the area with smell according to the participants. Unhygienic urinary and toilet facilities came up as causes of the insanitary situation of the stations and the markets. Apart from the mosquito bites that result in malaria attacks among the Kayayei, the deadly cholera disease had also been blamed on the bad sanitation situation in the station by participants. The findings indicated that the Kayayei living in these stations and markets take their meals in such unhygienic environment. This is clearly unwholesome eating habits that can be harmful to the health of the participant as highlighted below:

This market is full of filth and smells all the time. The situation is worse when it rains. We cannot cook our own food here, so we buy food, sometimes very cold from venders. This is the environment in which we eat and sleep. Cholera outbreak and malaria are common phenomena in this market, due to the dirty nature of the environment and excessive mosquito bites. The mosquitoes here are uncontrollable. We spend greater portion of our meagre income to buy drugs most of the time to treat ourselves.

The unhygienic state of the baths and toilets used by the Kayayei, in their residence claimed by the participants inform one of the risks the Kayayei are exposedto.The bad smell from the toilets and the gutters may also have caused other healthproblems that may not be known to the Kayayei. For (Shamsu-Deen, 2013), individual activities, such as poor lifestyle and unhealthy living environment work hand in hand to affect the health of Kayayei and other economic migrants. Mosquitobites predispose the Kayayei to malaria infection, and unfortunately resulted in the use of self-medication as a mode of treatment, which even expose them to more health risks. The unhealthy nature of the living experiences of economic migrants in their various living environments is a serious concern and had been widely acknowledged (Ogilvie, et al., 2007, Yeboah \& Appiah-Yeboah, 2009, World Health Organization, 2011). For theWorld Health Organization(2011), economic migrants, at their various destinations, are exposed to sicknesses, such as malaria, typhoid fever, cholera and reproductive health related problems as well as patronage of un-prescribed drugs and unregulated drug peddlers, which even put them at higher health risks.

\subsection{Physical Attacks and Verbal Abuse}

Physical assaults and verbal abuses by some sections of the public within the working areas of the Kayayeihavebeen noted by participants as a big challenge. Aside this, vehicular accidents at the lorry stations where the participants operate has also been reported as a serious concern to them.The crowd in the various markets and the stations according to participants, pull, push as well as insult them as they carry loads through such crowds; actions which could amount to physical and emotional harassment. The findings also indicated that some customers insult the Kayayei upon complains of being under-paid for services rendered. In fact, the living and working conditions of these economic migrants are poor and appalling, as stated below by a participant:

Our working condition is even more problematic. Sometimes, you are carrying a heavy load amidst the crowd of people in the market, and when you ask them to give you way to pass, they will not mind you. In such situations sometimes, you have to force yourself into the crowd to make way. But when you do so sometimes, they will keep insulting you as if you are not a human being, and some of them will even start pushing and pulling the load you are carrying. As a result, most of us treat neck pains weekly. With this our meagre income which is insufficient for our basic needs, some customersunderpay us for our services and insult us when we complain. We are suffering.

Participants in this study feel that their services to the public are not appreciated, because of the attitudes of some people towards them. The unfriendly physical abuse by some section of the public towards the Kayayei made them feel unfairly treated. This also contributes to the bodily pains most of the Kayayei experience.In line with above experiences the Kayayei go through, (Boateng and Korang-Okrah, 2013) asserted that the Kayayei went through harsher working and living experiences, such as the difficulties of carrying heavy loads and sometimes carrying babies at the same time through the overcrowded market lanes and busy roads, a situation which can be detrimental to their safety and health.Apart from the physical health effects the heavy loads they carry has on them, the Kayayei also attract small wages for carrying such heavy loads, which makes it difficult for them to meet their basic needs, for example, housing, food, water, sanitation and healthcare (King \& Amponsah, 2012).

The main working areas of the Kayayei are the lorry stations and in the markets. From the findings, the Kayayei carry loads around places characterized by heavy vehicular movement, which expose them to several vehicular accidents. Several Kayayei have been involved in motor accidents as retorted below by a participant:

The vehicular movement within our working environment is sometimes problematic for us. Several Kayayei have been knocked down by cars in the course of work in this station. Two of our sisters are currently undergoing treatment back in our hometown. The first one has a broken leg and the second person developed a waist problem and cannot even sit down properly on her own due to vehicular accidents.

Some Kayayei are now physically challenged as a result of the motor accidents in their working environment. One major negative consequence of migration is noted to do with the health challenges that result from the physical hardship and psychosocial experiences migrantsundergo (Kristiansen, Mygind, \& Krasnik, 2007). The challenge of exposure to motor accidents by the participants as they carry loads and move between and within cars in their various stations pose high risks to their health. From the findings a number of the Kayayei had been knocked down by cars and had been badly 
affected to the extent that one of the victims could not walk. This ordeal the Kayayei undergo in the kaya business has also been attested to by (Kwankye, et al., 2009) that the kaya business comes with certain risks, which include verbal and physical abuses.

\subsection{Availability of Health Services and Programmes}

It is expected that certain social support services be instituted by countries for the benefit of the poor, needy and the marginalized, such as the Kayayei in the society. Such social support and interventions among other things can be health services and programmes, such as free healthcare services, free and compulsory basic education and vocational training. However, participants reported from the findings in this study that these social interventions are not adequately available to them and sometimes difficult to access the available few. This is a voice of a participant:

Some groups do come here in the past to give health talks, even though such heath talks are not regular. I can remember that last New Year's Day, some religious groups came with medical officers, to talk to us on our reproductive health. They also talked to us about abstinence from sex, the need to and how to use both male and female condoms. They also talked about personal hygiene and sanitation and gaveus some gifts. That is all I can remember.

There are few programmes and services for the health needs of the Kayayei. However, the findings indicated that access to some of the few programmes and services available has been problematic for the Kayayei, due to poverty:

Some of us do not go to the clinic unless our sickness becomes so serious. We do not have money to register for the National Health Insurance Scheme (NHIS) cards. Only children under the age of eighteen and pregnant women do not pay for the NHIS card.

Even with the under eighteen, registration is not entirely free. I am sixteen years now, but myself and my mother did the NHIS registration two years ago, and she paid five Ghana cedis for mine. Now it may be more than that.

Access to health care service through the (NHIS) comes with a registration and yearly renewal cost, which is seen as an obstacle to the Kayayei. Some participants complained that the registration fee was preventing them from accessing the NHIS services.It is only appropriate that the International Labour Organization (2004)suggested to low income countries to initiate social welfare policies and programmes that will offer basic social and economic benefits to low-income persons, including migrants in the urban centres.It has been noted that, even when migrants were entitled to use health care services, they find it difficult to provide the resources needed to access such services (Gideon, 2011).This situation according to the findings, discourages the Kayayei from reporting to health centres when they fall sick and rather resort to unregulated drug dealers for treatment. Lack of adequate public healthcare facilities and services affect the health seeking behaviours of migrants (Adanu \& Johnson, 2009). This behaviour leads to drug abuse, which is even more harmful to the Kayayei. This implies that even though, the NHIS is aimed at increasing access to health care services by the poor and the vulnerable, including the Kayayei in society, extreme poverty and low-income levels frustrate access by these groups of people in the society.

\subsection{Limitation}

The study is purely a qualitative one, and generalization of findings on the Kayayei in general was not a requirement. Only eighteen (18) Kayayei out of a lot of the Kayayei working and living in Accra constitute the participants of this study. The findings of this study would have given a broader picture on the health challenges encountered by the Kayayei in general if a mixed method design approach was used. This will not only enable us to elicit the lived experiences and in-depth information from participants to meet the qualitative requirement of the studies butwill also allow usto select a representative sample size to cover a wider study area required to generalize findings on the population as quantitative design approach requires.

\section{Conclusions}

The kaya business engages over 10,000 Kayayei in Accra and over 50,000 Kayayei in the whole country as reported by (Wilson, \& Mittelmark, 2013). This implies that over 50,000 of Ghanaians are working or are self-employed in this business. However, from the findings of this study, lack of accommodation coupled with increasing number of the Kayayei in Accra, lead to overcrowding in their few indecent accommodations, such as verandas and market sheds, a situation which is detrimental to their health. With 8-48 years as the estimated age range for these economic migrants, it can be said that most of them are either not in school or are dropoutsfrom school, which denies them their fundamental human rightsand entitlements.We therefore, conclude that the harm the current kaya business causes to some of the Kayayei outweighs the benefits those Kayayei gain from the business. As such, the kaya business needs to be restructured to become more financially attractive and health friendly.

\section{Implication for Policy/ Practice}

The current living and working conditions of the Kayayei do not support their growth and development in so many areas of their lives and will require immediate attention. Specific areas for attention aretheir level of education and vocational training as well as accessible healthcare services. The need to support the Kayayei to grow and develop is an issue of national concern and government should work collaboratively with stakeholders such asgender-based organizations to organize vocational training for some of the Kayayei to equip them with employable skills to enable them find more dignifying jobsthan the kaya business. This may reduce their level of vulnerability and give them some high level of assertiveness that will equip them to have a stake in any decision that affects their lives. 
The situation of the Kayayei is a fertile ground for social workers to play their advocacy role to ensure that the Kayayei enjoy all their basic rights and entitlements, such as accessto basic and secondary educationfor those within the school going age. These when achieved, will enable theKayayei manage their lives and also take better decisions on their reproductive health, sexual and marital lives.

As a matter of policy, access to basic health care is free in Ghana with the inception of the National Health Insurance Scheme (NHIS). Stakeholders such as social workers as well as health workers should educate the Kayayei on the need to seek health care services and desist from taking un-prescribed drugs, which can sometimes worsen their health situation. Other gender-based NGOs can also support the Kayayeito register for the NHIS cards to enable them access health care services easily.

The current situation of the Kayayei does not give promising signals to Ghana's campaign in achieving the long overdue gender equality goal. Social Workers as central players of this campaign should put up a relentless effort to ensure the discharge of all the above duties and responsibilities for the Kayayei. When these duties and responsibilities of social workers are well discharged, it will go a long way to equip these girls with the needed skills for empowerment that will motivate them to strive hard to achieve this cherished worldwide ambition of gender equality.

\section{References}

i. Adanu, R. M. K., \& Johnson, T. R. B. (2009). Migrants and women's health. International Journal of Gynecology and Obstetrics, 106(2), 179-181.

ii. Anarfi, J. K. (1993). Sexuality, migration and AIDS in Ghana-A socio-behavioural study. Health Transition Review, 7(1), 45-67.

iii. Anarfi, J., Kwankye, S., Ababio, O. M., \& Tiemoko, R. (2003). Migration from and to Ghana: A background paper. University of Sussex: DRC on Migration, Globalisation and Poverty.

iv. Baah-Ennumh, T. Y., Amponsah, O., \& Owusu Adoma, M. (2012). The living conditions of female head porters in the Kumasi metropolis, Ghana. Journal of Social and Development Sciences, 3 (7), 229-244.

v. Blay, G. A. (2013). Awareness and Knowledge of Sexually Transmitted Infection among Female Porters in Madina (Doctoral dissertation, University of Ghana).

vi. Boateng, A., \& Korang-Okrah, R. (2013). The predicament of rural urban migration in Ghana: The case of the visible, but voiceless Kayayei girls. African Journal of Social Sciences, 3(4), 46-61.

vii. Carballo, M., \& Mboup, M. (2005). International migration and health. Paper presented at the Policy Analysis and Research Programme of the Global Commission on International Migration. Available at: www.gcim.org/ attachements/TP13.pdf (Accessed on the 20 May, 2015).

viii. Creswell, J. W., \& Miller, D. L. (2000). Determining validity in qualitative inquiry. Theory into practice, 39(3), 124130.

ix. Gideon, J. (2011). Exploring migrants' health seeking strategies: The case of Latin American migrants in London. International Journal of Migration, Health and Social Care, 7(4), 197-208.

x. International Labour Organization (2004). Gender and migration in Arab states: The case of domestic workers. ILO regional office for Arab states, Beirut

xi. King, R. S., \& Amponsah, O. (2012). The role of city authorities in contributing to the development of urban slums in Ghana. Journal of Construction Project Management and Innovation, 2(1), 285-313.

xii. Kristiansen, M, Mygind, A., \& Krasnik, A. (2007). Health effects of migration. Denmark Medical Bulleting, 54(1), 46-47.

xiii. Kwankye, S. O., Anarfi, J. K., Tagoe, C. A., \& Castaldo, A. (2007). Coping strategies of independent child migrants from northern Ghana to southern cities. Working Paper, T23. Brighton: Development Research Center on Migration, Globalization, and poverty, University of Suxxex.

xiv. Kwankye, S. O., Anarfi, J. K., Tagoe, C. A., \& Castaldo, A. (2009). Independent North-South child migration in Ghana: The decision making process. Development research centre on migration, globalisation and poverty, University of Sussex Working Paper T-29.

xv. Messias, D. K. H. (2002). Transnational health resources, practices, and perspectives: Brazilian immigrant women's narratives. Journal of Immigrant Health, 4(4), 183-200.

xvi. Ogilvie, L., Mill, J. E., Astle, B., Fanning, A., \& Opare, M. (2007). The exodus of health professionals from Sub-saharan Africa: Balancing human rights and societal needs in the twenty-first century. Nursing Inquiry, 14(2), 114-124.

xvii. O'neill, R. (2008). The advantages and disadvantages of qualitative and quantitative research Switzerland, Retrieved fromThe Qualitative Report, 15(3), 754-760.

xviii. Opare, J. A. (2003). Kayayei: The women head porters of southern Ghana. Journal of Social Development in Africa, 18(2), 33-48.

xix. Shamsu-Deen, Z. (2013). Migration and health nexus: A case of female porters (Kayayei) in Accra, Ghana. Research on Humanities and Social Sciences, 3(3), 103-109.

xx. Shamsu-Deen, Z. (3013). Following the trails of the mother: Migration and reproductive health nexus: A case study of female porter in Accra. International Journal of Science and Technology, 16(4), 1145-1159.

xxi. Srivastava, A., \& Thomson, S. B. (2009). Framework analysis: A qualitative methodology for applied policy research. Joaag, 4(2), 72-79.

xxii. Tanle, A., \& Awusabo-Asare, K. (2007). The kayayei phenomenon in Ghana: Female migration from the UpperWest region to Kumasi and Accra. The Oguaa Journal of Social Science, 4(2), 139-164. 
xxiii. Turner, D. W. (2010). Qualitative interview design: A practical guide for novice investigators. The Qualitative Report, 15(3), 754-760.

xxiv. United Nation Population Fund (2011). Kayayei female porters: Improving sexual and reproductive knowledge and legal literacy. Accra: UNFPA.

xxv. Van den Berg, C. (2007). The Kayayei: Survival in the city of Accra. Social capital and the vulnerability in the lives of female head porters in Accra, Ghana. A master thesis presented to the International School for Humanities and Social Sciences, University of Amsterdam.

xxvi. Whitehead, A. \&Hashim, I. (2005). Children and Migration. Background paper for DFID Migration Team. Department for International Development, London. Retrieved from www.migrationdrc.org/ research/ typesofmigration/ child mi gration.html on 5th August, 2015.

xxvii. Wilson, A., \& Mittelmark, M. B. (2013). Resources for adjusting well to work migration: Women from Northern Ghana working in head porterage in Greater Accra. Africa Today, 59(4), 24-38.

xxviii. World Health Organization (2008). Sixty-first world health assembly: Resolutions and decisions annexes. Geneva.

xxix. Yeboah, M. A., \& Appiah-Yeboah (2009). An examination of the cultural and social economic profiles of porters in Accra, Ghana. Nordic Journal of African Studies, 18(1), 1-21. 